\title{
งารสารวิศวกรSแศาสกร์
}

\section{การมอบหมายงานให้กับพนักงานขับรถที่มีรูปแบบการ เดินรถแบบต่อเนื่อง}

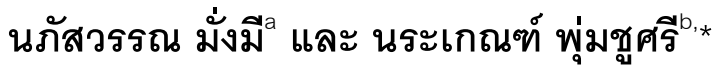

สาขาวิชาวิศวกรรมอุตสาหการ คณะวิศวกรรมศาสตร์ จุฬาลงกรณ์มหาวิทยาลัย กรุงเทพมหานคร 10330 ประเทศไทย อีเมล์: naphatsawan.m@student.chula.ac.tha , naragain.p@chula.ac.th ${ }^{\text {b,* }}$

บทคัดย่อ บทความวิจัยนี้นำเสนอการพัฒนาฮิวริสติก (Heuristic) สำหรับกระบวนการตัดสินใจมอบหมายงานให้กับ พนักงานขับรถในการทำงานที่มีรูปแบบการเดินรถแบบต่อเนื่อง ซึ่งรถสามารถทำงานรับ-ส่งสินค้าได้โดยไม่ถูกจำกัดด้วย ชั่วโมงการทำงานและสถานที่เริ่มต้น-สิ้นสุดการทำงาน เป็นการขนส่งที่พนักงานขับรถสามารถหยุดพักเมื่อครบรอบการ ทำงานได้ตามจุดต่าง ๆ ที่กำหนดให้และไม่จำเป็นที่จะต้องกลับมาพักยังจุดเริ่มต้นเสมอ โดยนำเสนอวิธีการตัดสินใจซึ่ง ออกเป็น 3 ขั้นตอนหลัก ขั้นตอนแรกเป็นการเลือกพนักงานขับรถที่มีความพร้อมในการทำงาน โดยพิจารณาจากตารางการ ทำงานของพนักงานขับรถและกับความต้องการการขนส่ง ขั้นตอนที่สองเป็นการจัดลำดับของรถเพื่อมอบหมายงานโดย พิจารณาจากแผนขนส่ง ขั้นตอนสุดท้ายเป็นการมอบหมายงานให้กับพนักงานขับรถ ซึ่งพิจารณาหาจุดเปลี่ยนที่เหมาะสมกับ ความพร้อมของพนักงานขับรถแต่ละคน โดยกระบวนการตัดสินใจมีวัตถุประสงค์เพื่อให้พนักงานขับรถสามารถทำงานรับ-ส่ง สินค้าได้ตามความต้องการของลูกค้า ด้วยค่าใช้จ่ายการเดินทางในระบบที่ต่ำ จากการทดสอบพบว่าวิธีฮิวริสติกที่พัฒนาขึ้น ซึ่งเป็นการวางแผนจากทุกเส้นทางทั้งหมดที่มีอยู่ (Multi-route) สามารถลดค่าใช้จ่ายในการเดินทางได้ประมาณ $15.23 \%$ เมื่อเปรียบเทียบกับวิธีการมอบหมายงานอย่างง่ายที่มาจากการวางแผนทีละเส้นทาง (Single-route)

คำสืบค้น: พนักงานขับรถ, การมอบหมายงาน, การเดินรถแบบต่อเนื่อง, ตารางพนักงานขับรถ

วารสารวิศวกรรมศาสตร์ (ISSN: 1906-3636) ปีที่ 4 ฉบับที่ 3

วันที่สง 18 ธันวาคม 2555

วันที่ตอบรับ 8 พฤษภาคม 2556

วันที่ตีพิมพ์ 31 พฤษภาคม 2556

Online at http://www.ej.eng.chula.ac.th/

DOI:10.4186/ejth.2012.4.3.37 


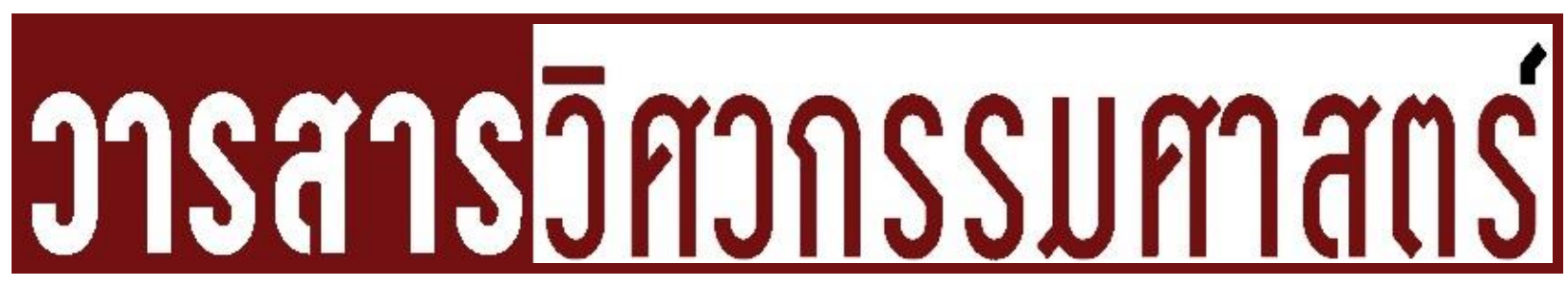

\title{
Driver Assignment for Continuous-Routing Vehicle
}

\author{
Naphatsawan Mungmee ${ }^{a}$ and Naragain Phumchusri ${ }^{b_{* *}}$
}

Department of Industrial Engineering, Faculty of Engineering, Chulalongkorn University, Bangkok 10330,

Thailand

E-mail: naphatsawan.m@student.chula.ac.th ${ }^{\mathrm{a}}$, naragain.p@chula.ac.th ${ }^{\mathrm{b}_{\text {, }}}$

Abstract. In this research paper, we develop a heuristic for driver assignment decision process in the continuous routing, which allows continuous transportation without limitation of truck operation hours and returning locations. In this system, drivers are allowed to take routine breaks at designated rest areas without having to return back to the hub. The decision process presented in this paper consists of three main steps. The first step provides a method of searching available drivers based on driver's scheduling and demands at any given time. The second step presents a method of selecting available vehicles and routes based on available vehicle fleet planning and logistics sequence, accordingly. The final step involves an assignment method of matching a driver to a selected job, taking into account of appropriate driver's switching points and his/her availability. The objective of this process is to find driver assignment decision that can meet customer's transportation requirement at a low travelling cost. From the computational experiments, the developed heuristic (with multi-route planning) can reduce the travelling cost by approximately $15.23 \%$ as compared to a simple single-route assignment method.

Keywords: Driver, job assignment, continuous-routing vehicle, driver schedule.

Engineering Journal (ISSN: 1906-3636) Volume 4 Issue 3

Received 18 December 2012

Accepted 8 May 2013

Published 31 May 2013

Online at http://www.ej.eng.chula.ac.th/

DOI:10.4186/ejth.2012.4.3.37 


\section{1. บทนำ}

สภาพการแข่งขันที่สูงขึ้นในปัจจุบัน ทำให้ผู้ประกอบการธุรกิจต่าง ๆ ต้องปรับตัวเพื่อเพิ่มความสามารถในการแข่งขัน เพิ่ม ความสามารถในการตอบสนองต่อความต้องการและความพึงพอใจของลูกค้า ภายใต้การบริหารงานที่มีประสิทธิภาพ ด้วย ต้นทุนที่ต่ำ การจัดการโลจิสติกส์ให้มีประสิทธิภาพเป็นกลยุทธ์หนึ่งที่สามารถลดต้นทุนรวมของสินค้าลงได้ ต้นทุนด้านการ ขนส่ง (Transportation Cost) เป็นหนึ่งในองค์ประกอบสำคัญของต้นทุนโลจิสติกส์ ซึ่งนับว่าเป็นหนึ่งต้นทุนที่สูงเมื่อ เปรียบเทียบกับต้นทุนด้านอื่น ๆ [1] การปรับเปลี่ยนรูปแบบการวิ่งของรถขนส่งเป็นหนึ่งในแนวทางในการลดต้นทุนที่เกิดจาก การขนส่ง ซึ่งรูปแบบการวิ่งรถขนส่งโดยทั่วไปมักเป็นการวิ่งแบบที่ต้องกลับมายังจุดเริ่มต้นเสมอ กล่าวคือ เมื่อหมดรอบเวลา การทำงาน รถขนส่งทุกคันจะกลับมายังจุดเริ่มต้นเมื่อเสร็จการทำงานขนส่ง แสดงดังรูปที่ 1 (a) ซึ่งการเดินรถแบบนี้ มักทำ ให้เกิดความสูญเสียจากการวิ่งรถเที่ยวเปล่ากลับมายังจุดเริ่มต้นเมื่อนำสินค้าไปส่งแล้ว และการวิ่งรถเที่ยวเปล่าไปรับสินค้า จากจุดต่าง ๆ ในระบบ

ปัจจุบันได้มีแนวทางการลดต้นทุนการขนส่งโดยการปรับปรุงวิธีการขนส่งให้มีการจัดการร่วมกันของโซ่อุปทาน (Supply Chain) ซึ่งทำให้เกิดการขนส่งสินค้ารูปแบบใหม่ ซึ่งเป็นการเดินรถที่มีการวิ่งอย่างต่อเนื่องตามคำสั่งการบริหารทรัพยากร แบบรวมศูนย์ การเดินรถลักษณะนี้ จะมีการวางแผนการขนส่งร่วมกันของส่วนต่าง ๆ ของโซ่อุปทาน เช่น ผู้ผลิต ผู้จัดหา วัตถุดิบ ผู้รับจ้างผลิต และลูกค้าต่าง ๆ โดยมีวัตถุประสงค์เพื่อให้มีระยะทางการวิ่งของรถขนสงน้อยลงด้วยการลดการวิ่ง เที่ยวเปล่า การเดินรถอย่างต่อเนื่องนี้ รถขนส่งสามารถทำงานรับ-ส่งสินค้าได้โดยไม่ถูกจำกัดด้วยชั่วโมงการทำงานและ สถานที่เริ่มต้น-สิ้นสุดการทำงาน เป็นการขนสงที่พนักงานขับรถสามารถหยุดพักเมื่อครบรอบการทำงานได้ตามจุดต่าง ๆ ที่ กำหนดให้และไม่จำเป็นจะต้องกลับมาพักยังจุดเริ่มต้นเสมอ และยังสามารถที่จะทำงานได้อย่างไม่มีข้อจำกัด วิ่งได้ระยะ ทางไกลขึ้น แสดงดังรูปที่ 1 (b)

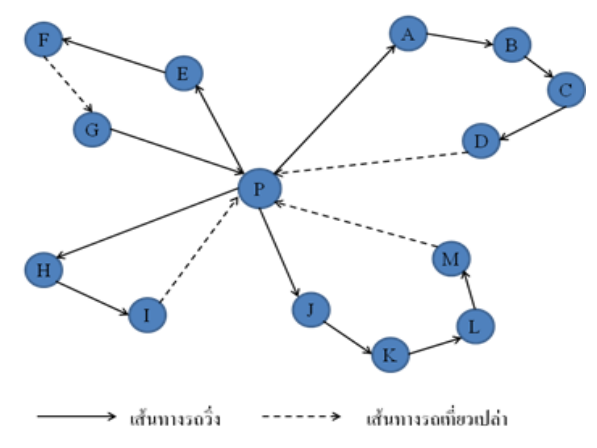

(a)

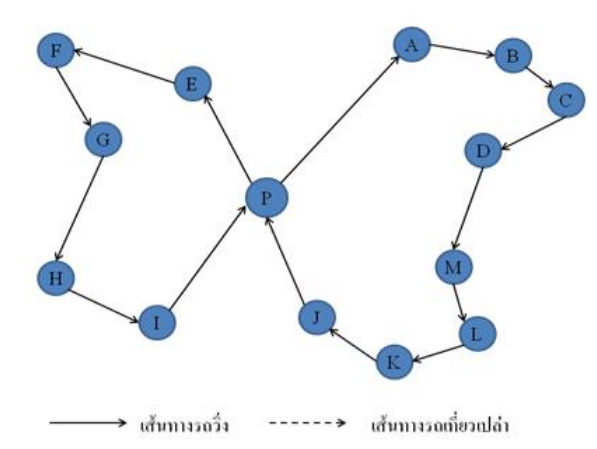

(b)

รูปที่ 1 รูปแบบการขนส่ง (a) ลักษณะเดิม (b) ลักษณะใหม่

เมื่อรูปแบบการวิ่งของรถเปลี่ยนไป ส่งผลให้รูปแบบการมอบหมายงานให้กับพนักงานขับรถย่อมเปลี่ยนไปด้วย การ มอบหมายงานหรือการจัดตารางการทำงานของพนักงานขับรถควรมีความสอดคล้องกับรูปแบบการวิ่งของรถขนส่ง รูปแบบ การวางแผนการขนส่งแบบเดิมที่พนักงานขับรถทำงานประจำในรถคันใดคันหนึ่งมีข้อจำกัด ที่เกิดจากเงื่อนไขของเวลาในการ ทำงานของพนักงานขับรถ กล่าวคือเมื่อพนักงานขับรถหมดรอบเวลาการทำงาน รถขนส่งคันนั้น ๆ ก็จะเกิดการพักการใช้งาน ไปด้วย นั่นหมายถึงรถขนส่งจะถูกใช้ตามรอบการทำงานของพนักงานขับรถ สำหรับลักษณะการเดินรถอย่างต่อเนื่องที่ผู้วิจัย พิจารณาในบทความวิจัยนี้ จะมีความต้องการเดินรถอย่างต่อเนื่องตามความต้องการการขนส่งที่ได้รับมา เพื่อให้เกิดการใช้ รถขนส่งอย่างมีประสิทธิภาพ เมื่อพนักงานขับรถคนหนึ่งครบรอบเวลาการทำงาน จะเกิดการสับเปลี่ยนให้พนักงานคนอื่นใน 
ระบบมาทำงานต่อ โดยลักษณะการทำงานแบบนี้จะเกิดการเคลื่อนย้ายหรือการเดินทางของพนักงานจากจุดหนึ่งเพื่อไปรับ งานที่อีกจุดหนึ่งในระบบ ซึ่งการตัดสินใจวางแผนว่าพนักงานคนใดจะทำงานใด โดยเริ่มต้นและสิ้นสุดงานที่ใดนั้น จึงเป็น การตัดสินใจที่มีความสำคัญ หากกระบวนการคิดไม่เหมาะสมหรือไม่มีประสิทธิภาพ ก็อาจทำให้เกิดค่าใช้จ่ายในการ เดินทางของพนักงานขับรถที่สูงได้

ดังนั้น วัตถุประสงค์ของงานวิจัยนี้คือการพัฒนาฮิวริสติก (Heuristic) สำหรับกระบวนการตัดสินใจมอบหมายงานให้กับ พนักงานขับรถในการทำงานที่มีรูปแบบการเดินรถแบบต่อเนื่อง โดยผลลัพธ์ที่ได้ของกระบวนการตัดสินใจคือ แผนการ มอบหมายงานให้กับพนักงานขับรถ ที่ระบุถึงข้อมูลของพนักงานขับรถ และข้อมูลการทำงานที่ได้รับมอบหมาย เช่น รหัสรถ ขนส่ง วัน-เวลาเริ่มต้นและสิ้นสุดการทำงาน เพื่อให้พนักงานขับรถสามารถทำงานรับ-ส่งสินค้าได้ตามความต้องการของ ลูกค้าด้วยค่าใช้จ่ายการเดินทางในระบบที่ต่ำ

\section{2. ทฤษฎีและงานวิจัยที่เกี่ยวข้อง}

ปัญหาการมอบหมายงาน (Assignment Model) เป็นการหาวิธีที่ดีที่สุดในการจัดคนให้เหมาะสมกับงาน โดยมีวัตถุประสงค์ เพื่อให้ได้เวลาทำงานรวมต่ำที่สุดหรือสามารถทำกำไรรวมได้สูงที่สุด ลักษณะปัญหาจะใกล้เคียงกับปัญหาการขนส่ง แต่มี ความแตกต่างที่รูปแบบของการมอบหมายงาน ซึ่งจำนวนคนจะต้องเท่ากับจำนวนงานและเมื่อมอบหมายงานให้คนใดคน หนึ่งรับงานไปแล้วจะไม่สามารถรับงานอื่นได้อีก $\quad$ [2] ซึ่งการหาคำตอบของปัญหาบางประเภท เช่น ปัญหาการจัดสรร ทรัพยากรที่มีอยู่อย่างจำกัดเพื่อให้เกิดประสิทธิภาพสูงสุด ปัญหาในการคำนวณต้นทุนต่ำสุด ฯลฯ สามารถหาคำตอบได้ หลายวิธี แต่วิธีการที่ง่ายที่สุดในการหาคำตอบคือ วิธีการทางฮิวริสติกต่าง ๆ ซึ่งอาจได้คำตอบที่ไม่ดีนัก [3] โดยการจัด ตารางงานสามารถกำหนดสมการวัตถุประสงค์ได้หลายวิธีดังนี้ 1) การกำหนดค่าใช้จ่ายให้การจัดตารางหรือค่าแรงงานรวม ทั้งหมดต่ำสุด 2) การกำหนดความยุติธรรมในการจัดสรรภาระงาน ซึ่งกำหนดให้มีความแตกต่างระหว่างค่าภาระงานสูงสุด และค่าภาระงานต่ำสุดน้อยที่สุด และการกำหนดให้มีค่าเบี่ยงเบนมาตรฐานน้อยที่สุด และ 3) การกำหนดความต้องการอื่น ๆ ที่ไม่ต้องการนับรวมไว้ในข้อจำกัดเป็นวัตถุประสงค์ของการจัดตารางงาน [4]

งานวิจัยที่เกี่ยวข้องส่วนใหญ่มุ่งเน้นการพิจารณาวางแผนเส้นทางขนส่ง ซึ่งมักจะคำนึงถึงแต่รถขนส่งเท่านั้น โดยไม่ได้ นำพนักงานขับรถมาพิจารณาวางแผนด้วย ซึ่งงานวิจัยที่เกี่ยวข้องกับการมอบหมายงานให้กับพนักงาน ส่วนมากจะพบใน รูปแบบการขนส่งด้านอื่น ๆ เช่น สายการบิน รถประจำทาง เป็นต้น ซึ่งแตกต่างจากรูปแบบการขนส่งในบทความวิจัยนี้ ที่มี รูปแบบการขนส่งโดยรถขนส่งในระบบที่มีความเกี่ยวข้องกับหลายสถานที่ เช่น การขนส่งระหว่างโรงงาน โรงงานกับลูกค้า โรงงานกับผู้จัดหาวัตถุดิบ โรงงานกับผู้รับจ้างผลิตภายนอก เป็นต้น ซึ่งแต่ละสถานที่ตั้งอยู่กระจายกันออกไปและมีระยะทาง ขนส่งแตกต่างกันและความต้องการใช้รถขนส่งเกิดขึ้นอย่างต่อเนื่อง ทำให้การวางแผนเส้นทางการขนส่งมักมีความไม่ แน่นอน ซึ่งสอดคล้องกับงานวิจัยของ Goel และคณะ [5] ได้กล่าวว่า เวลาการมาถึงของรถขนส่งสินค้าทางถนนจะมีความ ไม่แน่นอน โดยขึ้นอยู่กับความต้องการของลูกค้าและการวางแผนผลิตในแต่ละรอบเมื่อเทียบกับการขนส่งรูปแบบอื่น

และสำหรับการมอบหมายงานในการขนส่งด้านสายการบิน Anbil [6] ได้นำเสนอวิธีการที่ใช้ในการแก้ปัญหาการจัด ตารางการบินของลูกเรือ เพื่อให้มีค่าใช้จ่ายในการจัดการด้านสายการบินต่ำที่สุด และกล่าวถึงความซับซ้อนของปัญหาการ หาเส้นทางของลูกเรือว่ามาจากปัจจัยใด เช่น กฎเกณฑ์ที่กฎหมายกำหนดไว้ ซึ่งจะต้องนำมาเป็นเงื่อนไขของการจัดตาราง การบินด้วย จากนั้น Anbil [7] ได้ทำการศึกษาเพิ่มเติมจากเดิม [6] คือการพิจารณาจำนวนลูกเรือที่มีอยู่ในแต่ละฐานให้มี การเปลี่ยนแปลงเครื่องบินน้อยที่สุด โดยเลือกเส้นทางการบินที่มีระยะเวลาการบินน้อยสุดมาก่อน และส่งผลให้กรณีที่มีการ จัดตารางการบินใหม่ (Re-Schedule) เส้นทางการบินที่มีระยะเวลาการบินน้อยกว่าจะสามารถจัดตารางการบินใหม่ได้ง่าย 
กว่า นอกจากนั้น Yan และคณะ [8] ได้เสนอแนวทางของสายการบิน Taiwan ซึ่งมีวัตถุประสงค์เพื่อลดค่าใช้จ่ายของลูกเรือ และมีการวางแผนเส้นทางการบินของลูกเรือ โดยมีข้อจำกัดด้านกฎการทำงาน และได้เสนอให้สร้างผังของเส้นทางการบิน ของแต่ละวันเพื่อนำไปหาเส้นทางการบินของลูกเรือ โดยเส้นทางประกอบไปด้วยค่าใช้จ่ายในการทำงานแต่ละวัน ค่าใช้จ่าย บนพื้นดินและหาเส้นทางการบินของลูกเรือโดยวิธีหาเส้นทางที่สั้นที่สุด ซึ่งพบว่าการพิจารณาครอบคลุมเพียงการหาเส้นทาง การบินของนักบินทั้งหมดเท่านั้น แต่ไม่รวมถึงการจัดตารางการบินสำหรับนักบินแต่ละคน (Personal Schedule) นอกจาก การจัดตารางสายการบินแล้วการจัดตารางของรถขนส่งนั้น [5] ได้นำเสนองานวิจัยที่เกี่ยวกับการจัดตารางคนขับรถบรรทุก ในประเทศออสเตรเลีย โดยเสนอวิธีการแก้ปัญหาด้วยวิธีฮิวริสติกและนำเงื่อนไข 3 ประการ ได้แก่ ชั่วโมงการทำงาน มาตรฐาน การจัดการความเหนื่อยล้าพื้นฐานและการบริหารจัดการความเหนื่อยล้าขั้นสูงเข้ามาเกี่ยวข้องกับการวางแผน ซึ่ง มีการพิจารณาคนขับและชั่วโมงการทำงานจากตารางเดินรถที่มีอยู่ เพื่อเป็นการหาลำดับการเข้าของแต่ละสถานที่ โดยมี กรอบเวลาเข้ามาเกี่ยวข้องเพื่อให้เป็นไปตามกฎหมายของประเทศออสเตรเลีย จากนั้น Goel และคณะ [9] ได้นำเสนอ งานวิจัยที่เกี่ยวกับการจัดตารางคนขับรถบรรทุกในประเทศสหรัฐอเมริกา ซึ่งเป็นปัญหาที่เกี่ยวกับลำดับของการไปถึงของแต่ ละสถานที่โดยมีกรอบเวลา (Time Window) เข้ามาเกี่ยวข้องและนำเสนอเงื่อนไขเวลาในการทำงานของประเทศ สหรัฐอเมริกา นอกจากนี้ยังกล่าวว่า สำหรับการวางแผนการจัดตารางการทำงานนั้นจะมีวัตถุประสงค์และเงื่อนไขปัญหาที่ คล้ายคลึงกัน แต่แตกต่างกันในรูปแบบของการดำเนินธุรกิจ ประเภทของยานพาหนะ กฏหมายแรงงาน วัฒนธรรมและ รูปแบบการทำงานที่แตกต่างกันระหว่างท้องถิ่นแต่ละประเทศ

จากการศึกษางานวิจัยที่เกี่ยวข้อง สามารถสรุปความแตกต่างของรูปแบบการขนส่งในบทความวิจัยนี้กับรูปแบบการ ขนส่งอื่น ๆ ได้ดังนี้ (1) รูปแบบการขนส่งของสายการบิน เป็นตารางบินที่มีความแน่นอนทั้งเรื่องเวลาและเส้นทางการบิน มี การทำงานที่จุดเริ่มต้นและกลับมายังจุดเดิมเสมอ จึงทำให้สามารถระบุช่วงเวลาการทำงานของพนักงานที่แน่นอนได้ และ การพิจารณาวางแผนมอบหมายงานให้กับผู้ขับขี่เครื่องบินต้องเป็นไปตามกฎเกณฑ์ที่กฎหมายกำหนดไว้ และ (2) รูปแบบ การขนส่งของรถประจำทาง จะมีการดำเนินงานบนตารางเวลาและเส้นทางการวิ่งที่แน่นอน โดยพนักงานขับรถจะอยู่ประจำ รถคันใดคันหนึ่ง ซึ่งสามารถกำหนดงานเป็นรอบเวลาได้ นอกจากนั้น [6] กล่าวไว้ว่า การจัดตารางเวลาในการขับรถขนส่ง สินค้าทางถนนมีความแตกต่างกับการจัดตารางเวลาของลูกเรือในสายการบิน รวมถึงการจัดตารางเวลารถไฟหรือระบบ ขนส่งมวลชน ซึ่งการจัดตารางเวลารถไฟหรือระบบขนส่งมวลชนจะมีระบบการดำเนินงานบนตารางเวลาและเวลาการมาถึง ที่แน่นอน ในขณะที่เวลาการมาถึงของรถขนส่งสินค้าทางถนนจะมีความไม่แน่นอนและสามารถกำหนดได้เป็นอิสระมากกว่า อีกด้วย

ดังนั้นผู้วิจัยจึงได้นำการพิจารณาข้อจำกัดด้านเงื่อนไขเวลาในการทำงานของการขนส่งในรูปแบบต่าง ๆ มาประยุกต์ใช้ กับรูปแบบการขนส่งที่ผู้วิจัยสนใจในบทความวิจัยนี้

\section{3. รูปแบบของปัญหา}

งานวิจัยนี้เป็นการมอบหมายงานให้กับพนักงานขับรถขนส่ง ซึ่งจะพิจารณาจากแผนเส้นทางขนส่งที่มีการวางแผนไว้แล้ว เพื่อให้สามารถตอบสนองต่อการทำงานของรถขนส่งในรูปแบบวิ่งได้ต่อเนื่อง โดยมีค่าใช้จ่ายการเดินทางในระบบที่ต่ำ ซึ่ง รูปแบบการทำงานของรถขนสงที่ได้รับมาจากแผนเส้นทางขนส่งนั้น จะเป็นรูปแบบการวิ่งของรถโดยมีหลายฐานที่อยู่ (Home Bases) คือ เมื่อเสร็จการทำงานแล้วรถขนส่งไม่จำเป็นต้องกลับไปยังจุดเริ่มต้นเดิมเสมอ ดังนั้นการมอบหมายงาน สำหรับงานขนส่งในงานวิจัยนี้ คือ การวางแผนมอบหมายงานให้กับพนักงานขับรถขนส่ง ซึ่งเป็นการจัดตารางการทำงาน ของพนักงานขับรถ เพื่อสามารถตอบสนองต่อการทำงานของรถขนส่งในรูปแบบต่าง ๆ เนื่องจากทรัพยากรคนเป็นทรัพยากร 
ที่มีอยู่อย่างจำกัด จะวางแผนภายใต้กรอบเวลาที่มีอยู่เพื่อให้สามารถทำงานรับ-ส่งสินค้าได้ตามความต้องการของลูกค้าด้วย วิธีฮิวริสติก (Heuristic) ซึ่งรูปแบบการทำงานนั้นพนักงานขับรถสามารถจะหยุดพักได้ในหลาย ๆ จุดเมื่อหมดรอบเวลา ทำงานหรือถูกส่งไปทำงานที่อื่น โดยไม่จำเป็นที่จะต้องกลับมายังจุดเริ่มต้นเสมอและอาจจะมีการสับเปลี่ยนการทำงานกัน ระหว่างรถแต่ละคัน ไม่จำเป็นต้องอยู่ประจำรถคันใดคันหนึ่ง เพื่อเป็นการใช้ประโยชน์ของพนักงานขับรถที่มีอยู่อย่างเต็ม ประสิทธิภาพและลดค่าใช้จ่ายการเดินทางในระบบ โดยจุดเปลี่ยนพนักงานขับรถ คือจุดเปลี่ยนหรือพักการทำงานที่สามารถ นำมาพิจารณาให้กับพนักงานขับรถได้ สามารถเป็นได้ทั้งสถานที่รับ-ส่งสินค้าในระบบและจุดเปลี่ยนคนสำรอง (Dummy Node) ซึ่งความจำเป็นที่จะต้องมีการเพิ่มจุดเปลี่ยนคนสำรองเข้ามา เนื่องจากการเดินระหว่างจุดบางครั้งใช้เวลานาน ซึ่งจะ ช่วยเพิ่มทางเลือกในการเปลี่ยนหรือพักการทำงานของพนักงานขับรถโดยไม่จำเป็นจะต้องรอให้พนักงานขับรถทำงานจนถึง จุดที่เป็นแค่สถานที่รับ-สงงสินค้าในระบบเท่านั้น โดยจุดเปลี่ยนคนสำรอง คือจุดที่มีคุณสมบัติเพื่อการเปลี่ยนหรือพักของ พนักงานขับรถเท่านั้น แต่มิได้เป็นจุดรับและส่งสินค้า กรณีถ้าพนักงานขับรถขนส่งในระบบมีไม่เพียงพอ จะนำพนักงานขับรถ จากหน่วยงานภายนอก (Outsource) เข้ามาพิจารณาแทน โดยพิจารณาให้ทำงานเฉพาะช่วงเวลาที่พนักงานขับรถขนส่งใน ระบบไม่สามารถทำงานได้เท่านั้น เมื่อพนักงานขับรถขนส่งในระบบมีความพร้อมในการทำงานจะนำมาพิจารณาทันที โดย เลือกจุดเปลี่ยนพนักงานขับรถที่สามารถทำงานได้เร็วที่สุด ดังนั้นการวางแผนมอบหมายงานให้กับพนักงานขับรถขนส่งจะ เป็นการพิจารณาทุกเส้นทางที่ได้รับมาและมอบหมายงานให้พนักงานขับรถโดยมีข้อจำกัดด้านเวลาในการทำงาน นอกจากนี้ แล้วยังมีสมมติฐานและข้อจำกัดอื่น ๆ ของปัญหาวิจัยดังนี้

1. เวลา

- ผลรวมของเวลาการทำงานต่อวันและต่อสัปดาห์ ต้องไม่เกินจำนวนชั่วโมงการทำงานที่กำหนด

- เวลาในการขนสินค้าขึ้นรถ (Loading time) และเวลาในการขนสินค้าลงรถ (Unloading time) ถือว่าเป็นเวลา ที่พนักงานขับรถทำงาน และมีค่าน้อยมากจะรวมอยู่กับเวลาในทำงานแล้ว

- เวลาในการเดินทางระหว่างสถานที่จะแปรผันตามระยะทางและระหว่างสถานที่ 2 แห่ง ไม่จำเป็นต้องเท่ากัน

2. พนักงานขับรถ

- พนักงานขับรถสามารถเริ่มต้นและสิ้นสุดการทำงาน ณ จุดใดก็ได้ตามที่กำหนดไว้เมื่อหมดรอบการทำงานไม่ จำเป็นต้องกลับมายังจุดเริ่มต้นเดิมเสมอ

- พนักงานขับรถเมื่อได้หยุดตามจำนวนชั่วโมงที่กำหนดแล้ว จะกลับมาเริ่มต้นงาน ณ จุดสุดท้ายที่ทำงาน

- พนักงานขับรถจะมีทักษะ (Skill) ในการทำงานเท่ากัน โดยไม่มีการแบ่งอาณาเขต (Zone) หรือถูกจำกัดด้วย คุณสมบัติของสถานที่

3. โครงสร้างต้นทุน

- ต้นทุนค่าใช้จ่ายของพนักงานขับรถ พิจารณาจากค่าใช้จ่ายที่เกิดขึ้นจากการเดินทางเพื่อไปเริ่มงานหรื่อ สับเปลี่ยนการทำงานในจุดต่าง ๆ ของพนักงานขับรถ โดยแปรผันตามชั่วโมงการเดินทาง

- ต้นทุนค่าใช้จ่ายของพนักงานขับรถจากหน่วยงานภายนอก (Outsource) พิจารณาจากค่าใช้จ่ายที่เกิดจาก การเรียกใช้พนักงานขับรถจากหน่วยงานภายนอกคิดเป็นรายเที่ยวและค่าใช้จ่ายตามชั่วโมงการทำงานของ พนักงานขับรถ โดยแปรผันตามชั่วโมงการเดินทาง

เนื่องจากปัญหาการมอบหมายงานให้กับพนักงานขับรถโดยมีเงื่อนไขเวลาในการทำงานเป็นปัญหาที่ซับซ้อนยากต่อ การหาคำตอบ (NP-Hard) [10] ดังนั้นการแก้ปัญหาในงานวิจัยนี้จึงใช้วิธีฮิวริสติกซึ่งมีรายละเอียดดังหัวข้อถัดไป 


\section{4. แนวคิดและวิธีการแก้ปัญหา}

\section{1. แนวคิดของงานวิจัย}

งานวิจัยนี้เป็นการออกแบบระบบสนับสนุนการวางแผนมอบหมายงานให้กับพนักงานขับรถภายใต้กรอบเวลาที่มีอยู่เพื่อให้ สามารถทำงานรับ-ส่งสินค้าได้ตามความต้องการของลูกค้า โดยมีวัตถุประสงค์ทำให้ค่าใช้จ่ายการเดินทางในระบบที่ต่ำ ซึ่ง ค่าใช้จ่ายการเดินทาง (Moving Cost) คือค่าใช้จ่ายในการเดินทางเพื่อไปเริ่มต้นทำงานของพนักงานขับรถ ณ สถานที่ใด สถานที่หนึ่งตามแผนการมอบหมายงานจะแปรผันตามชั่วโมงการเดินทาง โดยค่าใช้จ่ายในการเดินทางจะเกิดขึ้นในช่วงเวลา ที่ไม่เกิดงานเป็นต้นทุนแปรผันที่ส่งผลต่อต้นทุนการขนส่ง ซึ่งสามารถพิจารณาหาวิธีการมอบหมายงานเพื่อให้มีค่าต่ำสุด และมีความแตกต่างกับค่าจ้างรายเดือนของพนักงานขับรถที่เป็นต้นทุนคงที่และไม่มีความเกี่ยวข้องกับงานที่กำลังพิจารณา มอบหมายงาน โดยกระบวนการหาคำตอบมีขั้นตอน 3 ส่วนดังนี้ (1) การเลือกพนักงานขับรถที่มีความพร้อมในการทำงาน (2) การจัดลำดับของรถเพื่อมอบหมายงาน และ (3) การมอบหมายงานให้กับพนักงานขับรถ ซึ่งมีกระบวนการตัดสินใจ แตกต่างกันในแต่ละขั้นตอนและสามารถใช้ข้อมูลบางอย่างร่วมกันได้ เพื่อใช้เป็นข้อมูลนำเข้าสูกระบวนการแก้ปัญหา เช่น ข้อมูลแผนเส้นทางขนส่ง ข้อมูลพนักงานขับรถ เป็นต้น

ภาพรวมของการมอบหมายงานให้กับพนักงานขับรถทั้ง 3 ส่วนนี้มีแนวคิดการตัดสินใจ แสดงดังรูปที่ 2 โดยที่ (1) พิจารณาหาพนักงานที่มีความพร้อมในการทำงาน โดยพิจารณาจากเวลาที่สามารถเริ่มงานได้ (Available Time) ของ พนักงานขับรถแต่ละคนจะต้องมีค่าน้อยกว่าหรือเท่ากับเวลาเริ่มต้นเร็วที่สุดที่สามารถทำได้ในรอบการพิจารณานั้น ๆ ของทุก เส้นทาง (Earliest start time: ES) จึงถือว่าเป็นผู้ที่มีความพร้อมในการทำงาน (2) พิจารณาจัดลำดับรถเพื่อมอบหมายงาน โดยพิจารณาจากเวลาเริ่มต้นในแต่ละเส้นทางและสถานะข้อมูลของพนักงานขับรถ การพิจารณาขั้นตอนนี้สามารถแบ่งการ พิจารณาได้เป็น 4 กรณี จะขอกล่าวในหัวข้อ "การแก้ปัญหาด้วยวิธีฮิวริสติก" ต่อไป และ (3) การมอบหมายงานให้กับ พนักงานขับรถ จะพิจารณาจุดเปลี่ยนพนักงานขับรถทุกจุดที่เป็นไปได้มาคำนวณเพื่อเปรียบเทียบกันในทุกเส้นทาง โดยการ พิจารณาจะต้องอยู่ภายใต้เงื่อนไขและข้อจำกัดด้านเวลาการทำงานของพนักงานขับรถด้วย ซึ่งจะพิจารณาเลือกจุดที่ให้ ค่าใช้จ่ายในการเดินทางเพื่อมาทำงานน้อยที่สุด และผลลัพธ์ที่ได้จากแนวคิดของการวางแผนมอบหมายงานให้กับพนักงาน ขับรถ คือ แผนการมอบหมายงานให้กับพนักงานขับรถ 


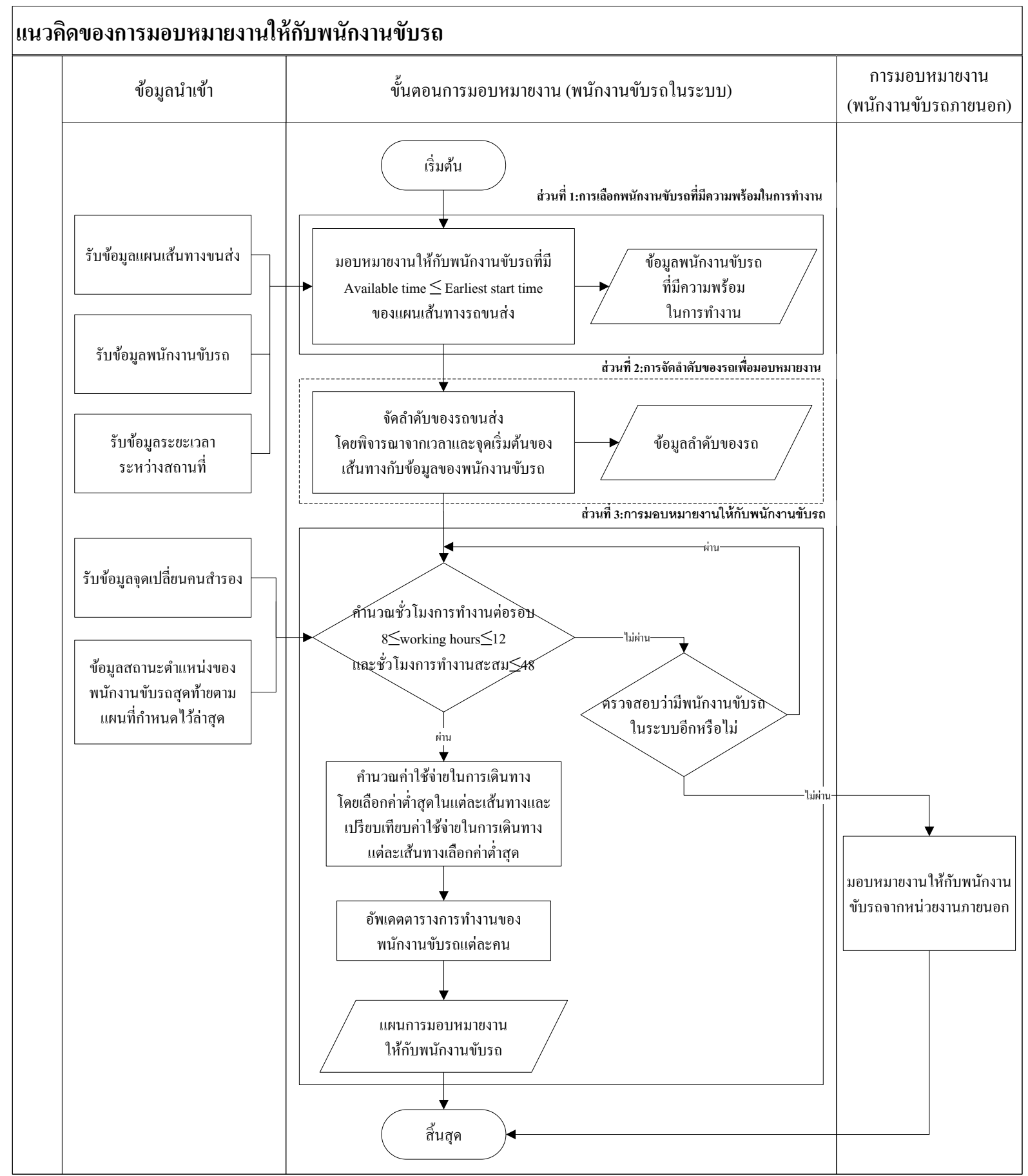

รูปที่ 2 ภาพรวมของกระบวนการมอบหมายงานให้กับพนักงานขับรถ

\section{2. การแก้ปัญหาด้วยวิธีฮิวริสติก}

\subsection{1. การเลือกพนักงานขับรถที่มีความพร้อมในการทำงาน}

ขั้นตอนนี้มีวัตถุประสงค์ เพื่อเป็นการหาพนักงานขับรถที่มีความพร้อมสำหรับการพิจารณามอบหมายงานให้ ในรอบของการ พิจารณาใด ๆ โดยมีข้อมูลนำเข้าเริ่มต้นคือ แผนเส้นทางขนส่งและสถานะการทำงานของพนักงานขับรถแต่ละคนในระบบ ซึ่ง Available Time คือเวลาที่สามารถเริ่มงานได้ของพนักงานขับรถแต่ละคน โดยจะต้องมีค่าน้อยกว่าหรือเท่ากับ เวลา 
เริ่มต้นการทำงานเร็วสุดที่สามารถทำงานได้ในรอบการคำนวณนั้น (Earliest Start Time, ES) จึงถือว่าพนักงานขับรถคนนั้น ๆ มีความพร้อมในการทำงาน มีการพิจารณาดังนี้

1. ตรวจสอบแต่ละเส้นทาง โดยพิจารณาหาเส้นทางที่มีเวลาเริ่มต้นการทำงานเร็วสุดที่สามารถทำงานได้ในรอบการ คำนวณนั้น

2. พิจารณาสถานะการทำงานของพนักงานขับรถ โดยพิจารณาจากเวลาที่สามารถเริ่มงานได้ (Available Time, $T a t_{j}$ ) ของพนักงานขับรถแต่ละคน คิดจากเวลาที่พนักงานขับรถสิ้นสุดการทำงานรอบก่อนหน้า $\left(T e t_{k}\right)$ รวมกับ เวลาพัก $\left(T r t_{j}\right)$ ยกเว้นพนักงานขับรถที่ทำงานยังไม่ครบรอบเวลาในรอบก่อนหน้าจะไม่รวมเวลาหยุดพัก ดัง สมการ (1)

$$
\operatorname{Tat}_{j}=\operatorname{Tet}_{k}+\operatorname{Trt}_{j} ; \operatorname{Trt}_{j}=\left\{\begin{array}{c}
0, W H_{k} \leq W H_{\text {lower }} \\
>0, W H_{k}>W H_{\text {lower }}
\end{array}\right.
$$

$\begin{array}{ll}\text { โดย } \mathrm{Tt}_{j} & \text { คือเวลาที่สามารถเริ่มงานได้ของพนักงานขับรถคนที่ } j ; j \subset D \\ \mathrm{Tet}_{k} & \text { คือเวลาสิ้นสุดการทำงานรอบที่ } k ; k \subset p \\ \mathrm{Trt}_{j} & \text { คือเวลาพักของพนักงานขับรถคนที่ } j ; j \subset D \\ W H_{k} & \text { คือจำนวนชั่วโมงการทำงานรอบที่ } k ; k \subset p \\ W H_{\text {lower }} & \text { คือชั่วโมงการทำงานน้อยสุดที่ยอมรับได้ } \\ j & \text { คือเซตของลำดับข้อมูลพนักงานขับรถขนส่งสินค้า } \\ k & \text { คือเซตลำดับของรอบการทำงาน } \\ D & \text { คือเซตของจำนวนพนักงานขับรถทั้งหมดในระบบ } \\ p & \text { คือเซตของจำนวนรอบการทำงานทั้งหมดที่กำลังพิจารณา }\end{array}$

3. หาพนักงานขับรถที่มีความพร้อมในการทำงานได้ โดยเวลาที่พนักงานขับรถสามารถเริ่มงานได้ ต้องน้อยกว่าหรือ เท่ากับเวลาเริ่มต้นการทำงานเร็วสุดที่สามารถทำงานได้ในรอบการคำนวณนั้น

โดยผลลัพธ์ที่ได้จากขั้นตอนนี้ คือข้อมูลพนักงานขับรถที่มีความพร้อมในการทำงาน และ นำไปใช้ในการวางแผน มอบหมายงานในขั้นตอน 4.2.3. ต่อไป

\subsection{2 การจัดลำดับของรถเพื่อมอบหมายงาน}

ขั้นตอนนี้มีวัตถุประสงค์เพื่อหาลำดับของรถขนส่งในการวางแผนมอบหมายงาน โดยมีข้อมูลนำเข้าเริ่มต้นคือ แผนเส้นทาง ขนส่ง ซึ่งจะนำเวลาเริ่มต้น (Starting Time) และจุดเริ่มต้น (Starting Node) การทำงานของรถขนส่งในทุกเส้นทางที่ได้รับมา พิจารณา ซึ่งเป็นการหาว่ารถขนสงคันใด ๆ ควรได้รับพิจารณามอบหมายหมายงานเป็นลำดับก่อนหลัง สามารถแบ่งได้เป็น 4 กรณี ดังนี้

- กรณีที่ 1 เวลาเริ่มต้นเท่ากันทั้งหมดและจุดเริ่มต้นจุดเดียวกันทั้งหมด พิจารณาเลือกเส้นทางใดขึ้นมาก่อนก็ได้

- กรณีที่ 2 เวลาเริ่มต้นไม่เท่ากันและจุดเริ่มต้นจุดเดียวกันทั้งหมด พิจารณาเลือกเส้นทางที่มีเวลาเริ่มต้นเร็วที่สุดก่อน

- กรณีที่ 3 เวลาเริ่มต้นเท่ากันทั้งหมดและจุดเริ่มต้นไม่ใช่จุดเดียวกันทั้งหมด

- กรณีที่ 4 เวลาเริ่มต้นไม่เท่ากันและจุดเริ่มต้นไม่ใช่จุดเดียวกันทั้งหมด

ในกรณีที่ 3 และ 4 ระบบจะพิจารณาตารางการทำงานของพนักงานขับรถร่วมด้วย มีขั้นตอนการพิจารณาดังนี้ 
1. เลือกเส้นทางที่รถขนส่งมีจุดเริ่มต้นการทำงานเดียวกับจุดที่พนักงานขับรถอยู่ขึ้นมาก่อน โดยเรียงลำดับตามเวลา เริ่มต้นเร็วสุดก่อน

2. พิจารณาทุกเส้นทาง ถ้าไม่มีเส้นทางใดที่รถขนส่งมีจุดเริ่มต้นการทำงานเดียวกันกับจุดที่พนักงานขับรถอยู่แล้ว จะ เลือกเส้นทางที่รถขนส่งมีจุดเริ่มต้นที่พนักงานขับรถสามารถเดินทางมาเริ่มต้นทำงานได้ใกล้ที่สุดก่อน

โดยผลลัพธ์ที่ได้จากขั้นตอนนี้ คือข้อมูลลำดับรถขนส่งเพื่อการมอบหมายงาน และจะไปนำไปใช้ในการวางแผน มอบหมายงานในขั้นตอนถัดไป

\subsection{2. การมอบหมายงานให้กับพนักงานขับรถ}

ขั้นตอนนี้มีวัตถุประสงค์เพื่อหาพนักงานขับรถที่มีความพร้อมในการทำงานกับจุดเปลี่ยนพนักงานขับรถที่ทำให้เกิดค่าใช้จ่าย ในการเดินทางต่ำที่สุด มีข้อมูลนำเข้าเริ่มต้นคือ แผนเส้นทางขนส่ง ข้อมูลระยะเวลาระหว่างจุด ข้อมูลจุดเปลี่ยนคนสำรอง ข้อมูลพนักงานขับรถและรับข้อมูลตำแหน่งสุดท้ายของพนักงานขับรถจากแผนรอบก่อนหน้าที่กำหนดแน่นอนแล้ว โดยจะนำ พนักงานขับรถที่มีความพร้อมในการทำงานและลำดับของรถที่ได้จากขั้นตอนก่อนหน้านี้มาร่วมพิจารณา โดยจะมีเกณฑ์การ พิจารณา คือชั่วโมงการทำงานต่อรอบ กำหนดให้เป็นช่วงระยะเวลาของชั่วโมงการทำงานต่ำสุดที่ยอมรับได้ (Lower Working Hours) และชั่วโมงการทำงานสูงสุดที่ยอมรับได้ (Upper Working Hours) รวมถึงชั่วโมงการทำงานสะสม คือ ผลรวมของชั่วโมงการทำงานรอบก่อนหน้าทั้งหมดรวมกับชั่วโมงการทำงานในรอบที่กำลังพิจารณาอยู่ จะต้องเป็นไปตาม เงื่อนไขที่กำหนด ซึ่งสามารถแบ่งขั้นตอนย่อยเป็น 3 ขั้นตอนดังนี้

ขั้นตอนที่ 1 การพิจารณาสถานะพนักงานขับรถจากรอบก่อนหน้า โดยจากแผนเส้นทางขนส่งที่มีอยู่จะพิจารณาดังนี้

(1) ตรวจสอบสถานะรอทำงาน (Waiting Status) จากสถานะการทำงานของพนักงานขับรถ ต้องระบุเป็นสถานะ รอทำงาน คือสถานะที่พนักงานขับรถทำงานไม่ครบชั่วโมงการทำงาน จากชั่วโมงการทำงานต่ำสุดที่ยอมรับได้ และชั่วโมงการทำงานสูงสุดที่ยอมรับได้ที่ถูกกำหนดไว้ของรอบก่อนหน้า ซึ่งรอบก่อนหน้า หมายถึงรอบการ พิจารณาล่าสุดที่ได้มอบหมายงานให้กับพนักงานขับรถไปแล้ว

(2) ตรวจสอบเวลารอทำงาน (Waiting Time) และสถานที่รอทำงาน (Waiting Place) ของพนักงานขับรถตรงกับ จุดเริ่มต้นของเส้นทางที่กำลังพิจารณาอยู่หรือไม่ โดยพิจารณาว่าแต่ละเส้นทางมีสถานที่เริ่มต้น (Starting Place) และเวลาเริ่มต้น (Starting Time) ตรงกับเวลา (Available Time) และสถานที่ (Available Place) ที่ พนักงานขับรถพร้อมทำงานหรือไม่

- จากการตรวจสอบหากเป็นไปตามเงื่อนไข จะมีการคำนวณหาจุดเปลี่ยนให้พนักงานขับรถทำงานต่อยัง จุดนั้นดังขั้นตอนที่ (3)

- หากไม่เป็นตามเงื่อนไข จะไม่พิจารณามอบหมายงานให้พนักงานขับรถคนนั้นต่อและกำหนดให้พนักงาน ขับรถได้พักการทำงานทันที

(3) คำนวณหาจุดเปลี่ยนพนักงานขับรถ พิจารณาจากจุดเปลี่ยนหรือพักการทำงานที่เกิดขึ้นจากจำนวนชั่วโมง การทำงานที่สามารถทำงานต่อได้ โดยต้องมีผลรวมของชั่วโมงการทำงานอยู่ในช่วงชั่วโมงการทำงานต่ำสุด และสูงสุดที่ยอมรับได้ตามที่กำหนดไว้ ซึ่งจะต้องนำเอาชั่วโมงการทำงานที่ได้ทำงานไปแล้วรอบก่อนหน้ามา คิดด้วย 
(4) คำนวณชั่วโมงการทำงานสะสม $\left(W H_{c u m}\right)$ คือผลรวมของชั่วโมงการทำงานรอบก่อนหน้าทั้งหมด $\left(W H_{k}\right)$ รวมกับชั่วโมงการทำงานในรอบที่กำลังพิจารณาด้วย โดยที่ผลรวมของชั่วโมงการทำงานสะสม จะต้องไม่เกิน ชั่วโมงการทำงานรวมสูงสุดที่ยอมรับได้ $\left(W H_{s u m}\right)$

- จากการตรวจสอบหากเป็นไปตามเงื่อนไข จึงจะมีการพิจารณามอบหมายงานให้พนักงานขับรถทำงาน และอัพเดตตารางการทำงานดังขั้นตอนที่ (5)

- หากไม่เป็นตามเงื่อนไขขั้นตอนที่ (4) จะมีการคำนวณวันหยุดให้พนักงานขับรถดังขั้นตอนที่ (6) และทำ การอัพเดตตารางการทำงานดังขั้นตอนที่ (5)

(5) อัพเดตตารางการทำงาน คือเมื่อมีการมอบหมายงานให้กับพนักงานขับรถไปแล้ว จะทำการปรับตารางการ ทำงานของพนักงานขับรถ เพื่อหาเวลาที่สามารถเริ่มต้นทำงานได้ในรอบถัดไป ดังสมการ (1) และสถานที่ เริ่มต้นพร้อมทำงานในรอบถัดไป จะเป็นสถานที่เดียวกับสถานที่สิ้นสุดการทำงานในรอบก่อนหน้านี้

(6) คำนวณวันหยุด คือเมื่อพนักงานขับรถมีจำนวนชั่วโมงการทำงานสะสมใกล้เคียง (น้อยกว่าหรือเท่ากับ) กับ ชั่วโมงการทำงานรวมสูงสุดที่ยอมรับได้มากที่สุด และพบว่าพนักงานไม่สามารถทำงานรอบต่อไปได้อีกจะมี การพิจารณาชั่วโมงวันหยุด $(S W)$ ให้กับพนักงานขับรถ และจากชั่วโมงการทำงานรวมสูงสุดที่ยอมรับได้ใน รอบนั้นบวกกับชั่วโมงวันหยุดของพนักงาน ทำให้สามารถหาเวลาพร้อมทำงานของพนักงานขับรถในรอบ ถัดไปได้

ขั้นตอนที่ 2 การหาจุดเปลี่ยนพนักงานขับรถ ขั้นตอนนี้พิจารณาเลือกเส้นทางรถขนส่งจากลำดับของรถที่ได้จากขั้นตอน ที่ 4.2 .2 จากนั้น

(7) เลือกพนักงานขับรถเพื่อมาทำงานยังจุดเริ่มต้นของรถขนส่งในแต่ละเส้นทาง เป็นการหาว่าพนักงานคนใดที่จะ เริ่มทำงานยังจุดเริ่มต้นของรถขนส่งในแต่ละเส้นทาง โดยจุดเปลี่ยนพนักงานขับรถที่เกิดขึ้นนั้น สามารถเป็นได้ ทุกจุดที่พนักงานขับรถมีจำนวนชั่วโมงการทำงานที่สามารถทำงานได้ โดยต้องมีผลรวมของชั่วโมงการทำงาน อยู่ในช่วงชั่วโมงการทำงานต่ำสุดและสูงสุดที่ยอมรับได้ตามที่กำหนดไว้ ซึ่งจะต้องนำเอาชั่วโมงการทำงานที่ ได้ทำงานไปแล้วรอบก่อนหน้ามาคิดด้วย เนื่องจากพนักงานขับรถที่นำมาพิจารณาจะไม่มีสถานะรอทำงาน จากรอบก่อนหน้า ดังนั้นทำให้ชั่วโมงการทำงานที่ได้ทำงานไปแล้วรอบก่อนหน้าในขั้นตอนมีค่าเท่ากับ 0

(8) ทำซ้ำในขั้นตอนที่ (4)

- จากการตรวจสอบหากเป็นไปตามเงื่อนไข จึงจะมีการพิจารณาเลือกค่าใช้จ่ายในการเดินทางน้อยที่สุดดัง ขั้นตอนที่ (9)

- หากไม่เป็นตามเงื่อนไขขั้นตอนที่ (8) จะมีการคำนวณวันหยุดให้พนักงานขับรถดังขั้นตอนที่ (6) และทำ การอัพเดตตารางการทำงานดังขั้นตอนที่ (5)

- หากไม่เป็นตามเงื่อนไขขั้นตอนที่ (7) หรือขั้นตอนที่ (7) และ (8) จะไม่พิจารณามอบหมายงานให้ พนักงานขับรถคนนั้น และจะมีการคำนวณวันหยุดให้พนักงานขับรถดังขั้นตอนที่ (6) และทำการอัพเดต ตารางการทำงานดังขั้นตอนที่ (5)

(9) เลือกค่าใช้จ่ายในการเดินทางน้อยที่สุด เป็นการเลือกพนักงานขับรถมาทำงานยังจุดเริ่มต้นการทำงานรอบ ถัดไป กรณีถ้ามีพนักงานขับรถที่สามารถทำงานได้มากกว่า 1 คน จะพิจารณาเลือกพนักงานขับรถที่มี ค่าใช้จ่ายในการเดินทางเพื่อมาเริ่มต้นทำงานน้อยที่สุดในจุดเริ่มต้นของแต่ละเส้นทาง

(10) ทำซ้ำขั้นตอนที่ (5) 
(11) สร้างทางเลือก (Combination) ของจุดที่สามารถเป็นจุดเปลี่ยนพนักงานขับรถได้ หาได้จากเวลาเริ่มต้นการ ทำงานรอบใด ๆ บวกกับจำนวนชั่วโมงการทำงานรอบใด ๆ ซึ่งจำนวนชั่วโมงการทำงานรอบใด ๆ จะมีค่า เท่ากับจำนวนชั่วโมงการทำงานที่สามารถทำงานได้ โดยต้องมีค่าอยู่ในช่วงของชั่วโมงการทำงานต่ำสุดและ สูงสุดที่ยอมรับได้ที่ยอมรับได้

(12) ทำซ้ำขั้นตอนที่ (7) และ $(8)$ ตามลำดับ

- จากการตรวจสอบหากเป็นไปตามเงื่อนไขทั้ง 2 ขั้นตอน จึงจะมีการพิจารณาเลือกค่าใช้จ่ายในการ เดินทางน้อยที่สุดดังขั้นตอนที่ (9)

- หากไม่เป็นตามเงื่อนไขขั้นตอนที่ (7) หรือขั้นตอนที่ (7) และ (8) จะมีการคำนวณวันหยุดให้พนักงานขับ รถดังขั้นตอนที่ (6) และทำการอัพเดตตารางการทำงานดังขั้นตอนที่ (5) นอกจากนั้นจะมีการตรวจสอบ ว่ามีพนักงานขับรถในระบบเพียงพอหรือไม่ ดังขั้นตอนที่ (15)

(13) เปรียบเทียบแต่ละเส้นทางแล้วเลือกค่าใช้จ่ายในการเดินทางที่น้อยที่สุด

(14) ทำซ้ำขั้นตอนที่ (5)

(15) ตรวจสอบว่ามีเส้นทางที่ยังไม่ได้มอบหมายงานอีกหรือไม่

- จากการตรวจสอบหากพบว่ามีเส้นทางใดที่ยังไม่ได้มอบหมายงาน จะวนกลับไปทำซ้ำตั้งแต่ขั้นตอนที่ (7)

- หากไม่มีเส้นทางใดที่ยังไม่ได้มอบหมายงานเหลืออยู่ จะได้ผลลัพธ์ คือแผนการมอบหมายงานให้กับ พนักงานขับรถ

จากกระบวนการนี้ผลลัพธ์สุดท้ายที่ได้ คือแผนการมอบหมายงานให้กับพนักงานขับรถ มีวัตถุประสงค์เพื่อทำให้เกิด ค่าใช้จ่ายในการเดินทางต่ำ สามารถเขียนสมการวัตถุประสงค์ได้ดังสมการ (2) กล่าวคือ

$$
\operatorname{Min} \sum M=\sum T_{a b j}+C_{\text {out }}
$$

โดย $M$

คือค่าใช้จ่ายในการเดินทางของระบบ

$T_{a b j}$ คือระยะเวลาเดินทางจากสถานที่ $a$ ไปสถานที่ $b$ ของพนักงานขับรถคนที่ $j ; a, b \subset N$ และ $j \subset D$

$C_{\text {out }}$ คือค่าใช้จ่ายที่เกิดขึ้นจากการจ้างพนักงานขับรถจากหน่วยงานภายนอก

หากพนักงานขับรถในระบบมีจำนวนเพียงพอต่อการมอบหมายงาน จะไม่มีค่าใช้จ่ายที่เกิดจากการจ้างพนักงานขับรถ จากหน่วยงานภายนอกเข้ามาพิจารณา ดังนั้นจากสมการ (2) $C_{\text {out }}$ จะมีค่าเท่ากับ 0 และค่าใช้จ่ายในการเดินทางจะแปรผัน ตามระยะเวลาเดินทางจากสถานที่ $a$ ไปสถานที่ $b$

\section{ขั้นตอนที่ 3 การพิจารณาพนักงานขับรถจากหน่วยงานภายนอก}

(16) ตรวจสอบว่ามีพนักงานขับรถในระบบอีกหรือไม่

- จากการตรวจสอบหากพบว่ามีพนักงานขับรถในระบบเพียงพอ จะวนกลับไปทำซ้ำตั้งแต่ขั้นตอนที่ (7)

- หากถ้ามีจำนวนไม่พอจะนำพนักงานขับรถจากหน่วยงานภายนอกเข้ามาพิจารณา

โดยค่าใช้จ่ายของพนักงานขับรถจากหน่วยงานภายนอก ได้จากผลรวมของค่ารายเที่ยวที่เกิดขึ้นจากการจ้าง พนักงานขับรถจากหน่วยงานภายนอก $\left(R_{\text {out }}\right)$ บวกกับจำนวนชั่วโมงการทำงานที่เกิดขึ้นจากการจ้างพนักงานขับ รถจากหน่วยงานภายนอก $\left(W H_{o u t}\right)$ โดยที่ $C_{o u t}=0$ หากไม่มีการจ้างพนักงานขับรถจากหน่วยงานภายนอก

(17) หาเวลาเร็วที่สุดที่พนักงานขับรถในระบบจะกลับมาทำงานได้ ซึ่งจะนำเวลาที่สามารถเริ่มงานได้ของพนักงาน ขับรถมาพิจารณา โดยเลือกจากพนักงานขับรถที่สามารถกลับมาเริ่มทำงานได้เร็วที่สุด 
(18) ตรวจสอบช่วงเวลาที่พิจารณาว่ามีจุดเปลี่ยนพนักงานขับรถหรือไม่ ขั้นตอนนี้นำเวลาที่สามารถเริ่มงานได้ของ พนักงานขับรถมาพิจารณาเปรียบเทียบกับจุดเปลี่ยนพนักงานขับรถที่สามารถเกิดขึ้นได้ โดยเลือกจุดเปลี่ยน พนักงานขับรถที่มีเวลาเร็วสุดที่สามารถให้พนักงานขับรถในระบบสามารถกลับมาเริ่มทำงานได้

\section{5. ผลการทดสอบฮิวริสติก}

ในงานวิจัยนี้ผู้วิจัยได้ทดสอบฮิวริสติกที่ถูกสร้างขึ้นจากโปรแกรม Microsoft Visual Basic 2010 ซึ่งได้ทำการประเมิน คุณภาพของคำตอบที่ได้โดยแบ่งการทดสอบออกเป็น 2 ประเด็นดังนี้

1. การทดสอบเพื่อหาปัจจัยที่ส่งผลต่อระบบ

2. ทดสอบกับวิธีการอื่น

\section{1. การทดสอบเพื่อหาปัจจัยที่ส่งผลต่อระบบ}

เป็นการทดสอบเพื่อหาปัจจัยที่ส่งผลกับคำตอบที่ได้จากวิธีฮิวริสติกที่ผู้วิจัยพัฒนาขึ้น โดยพิจารณาว่าปัจจัยต่าง ๆ เหล่านี้ สงผลกับคุณภาพของคำตอบอย่างไร ปัจจัยที่ศึกษามีดังต่อไปนี้

1. ชั่วโมงการทำงานต่อครั้ง หมายถึงจำนวนชั่วโมงการทำงานที่พนักงานขับรถสามารถทำงานได้ใน 1 รอบการทำงาน โดยชั่วโมงการทำงานต่อครั้งในการทดสอบพิจารณามาจาก

วิธีที่ 1 ฮิวริสติกที่พัฒนาขึ้น หมายถึงการกำหนดชั่วโมงการทำงานต่อครั้งเป็นชั่วโมงการทำงานต่ำสุดที่ยอมรับได้ เท่ากับ 8 ชั่วโมงและชั่วโมงการทำงานสูงสุดที่ยอมรับได้เท่ากับ 12 ชั่วโมง ดังนั้นการพิจารณามอบหมายงานให้กับ พนักงานขับรถจะเลือกจุดเปลี่ยนพนักงานขับรถเมื่อพนักงานขับรถมีชั่วโมงการทำงานได้ $8,9,10,11$ หรือ 12 ชั่วโมง ซึ่ง กระบวนการคิดจะนำทุกจุดเปลี่ยนพนักงานขับรถที่สามารถเป็นไปได้มาคำนวณเพื่อเปรียบเทียบหาค่าใช้จ่ายในการเดินทาง ที่เกิดขึ้นในทุกเส้นทาง ซึ่งจะพิจารณาเลือกจุดที่ให้ค่าใช้จ่ายในการเดินทางต่ำที่สุด สามารถอธิบายได้ดังรูปที่ 3 (a)

วิธีที่ 2 ชั่วโมงการทำงานต่อครั้งสูงสุด หมายถึงชั่วโมงการทำงานต่อครั้งที่จัดให้ได้ใกล้เคียงชั่วโมงสูงสุดที่ทำได้ ซึ่งในงานวิจัยนี้กำหนดเท่ากับ 12 ชั่วโมง สามารถอธิบายได้ดังรูปที่ $3(\mathrm{~b})$

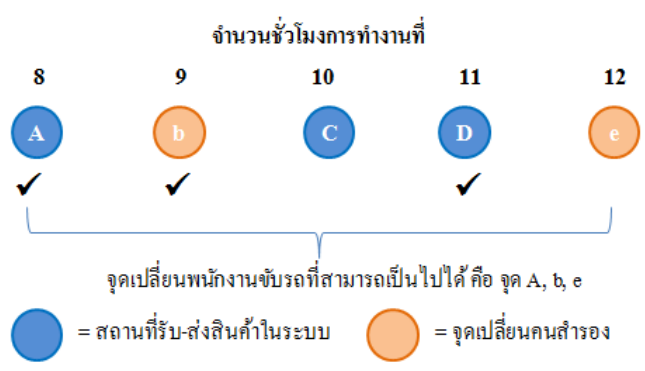

(a)

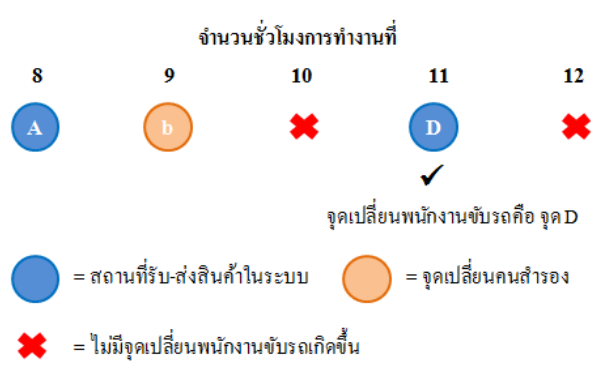

(b)

รูปที่ 3 การพิจารณาหาจุดเปลี่ยนพนักงานขับรถที่เป็นไปได้ (a) ฮิวริสติกที่พัฒนาขึ้น (b) ชั่วโมงการทำงานต่อครั้งสูงสุด

การทดสอบจะนำค่าใช้จ่ายในการเดินทางจากปัจจัยทั้ง 2 แบบมาเปรียบเทียบกัน โดยอาศัยโจทย์ปัญหาที่มีชุดข้อมูล 2 ชุด แต่ละชุดประกอบด้วยข้อมูล 60 ตัวอย่าง ซึ่งชุดข้อมูลจะแบ่งตามชั่วโมงการทำงานต่อครั้งที่พิจารณา และคำถามในการ ทดสอบนี้คือ ชั่วโมงการทำงานต่อครั้งที่แตกต่างกันมีผลต่อค่าใช้จ่ายในเดินทางหรือไม่อย่างไร ภายใต้โจทย์ปัญหาที่มีข้อมูล ชุดเดียวกัน โดยผลการทดสอบแสดงดังรูปที่ 4 (ข้อมูลเส้น $C$ และ $D$ ) พบว่าการพิจารณาชั่วโมงการทำงานเท่ากับ $8-12$ 
ชั่วโมงต่อครั้งส่งผลให้จำนวนชั่วโมงการเดินทางมีค่าน้อยกว่าชั่วโมงการทำงานแบบจัดให้ได้ใกล้ เคียงชั่วโมงสูงสุดที่ทำได้ (12 ชั่วโมง) โดยเปอร์เซ็นต์ความแตกต่างอธิบายได้ดังสมการ (3)

$\%$ ความแตกต่างจำนวนชั่วโมงการทำงาน $=$

ชั่วโมงการเดินทางจากวิธีที่ 2 - ชั่วโมงการเดินทางจากวิธีที่ 1

ชั่วโมงการเดินทางจากวิธีที่ 2

จากการทดสอบโจทย์ปัญหาทั้ง 60 ตัวอย่างพบว่า ค่าเฉลี่ยของเปอร์เซ็นต์ความแตกต่างเท่ากับ $15.66 \%$ และจากกราฟ รูปที่ 4 จะเห็นได้ว่า เมื่อระยะเวลาโดยเฉลี่ยของการเดินทางภายในกลุ่มเพิ่มมากขึ้นจะได้ค่าความแตกต่างของทั้ง 2 คำตอบ เพิ่มขึ้นเช่นกัน เนื่องจาก

- การพิจารณามอบหมายงานที่กำหนดให้มีชั่วโมงการทำงานเท่ากับ $8-12$ ชั่วโมงต่อครั้ง จะส่งผลให้มีจุดเปลี่ยน พนักงานขับรถที่เป็นไปได้มีจำนวนเพิ่มขึ้น ซึ่งการพิจารณาเปรียบเทียบหาจุดที่เหมาะสมจะมีได้หลายจุดมากกว่า และทำให้มีโอกาสเปรียบเทียบเลือกจุดที่ดีที่สุด ซึ่งส่งผลให้จำนวนชั่วโมงการเดินทางมีค่าน้อยกว่าเช่นกัน

- การพิจารณามอบหมายงานที่กำหนดให้มีชั่วโมงการทำงานแบบจัดให้ได้ใกล้เคียงชั่วโมงสูงสุดที่ทำได้ (12 ชั่วโมง) เป็นการพิจารณาหาจุดเปลี่ยนพนักงานขับรถที่เลือกมาจากจุดใด ๆ ที่พนักงานขับรถสามารถทำงานได้ครบรอบ เวลาการทำงานมากที่สุดเท่านั้น โดยไม่ได้คำนึงถึงการเปรียบเทียบหาจุดที่เหมาะสมและส่งผลต่อจำนวนชั่วโมง การเดินทางแต่อย่างใด

สรุปได้ว่า ชั่วโมงการทำงานต่อครั้งที่แตกต่างกันมีผลต่อจำนวนชั่วโมงการเดินทาง ซึ่งชั่วโมงการทำงานแบบ $8-12$ ชั่วโมงต่อครั้งให้ค่าใช้จ่ายในการเดินทางที่แปรผันตามจำนวนชั่วโมงการเดินทางนั้นมีค่าน้อยกว่าชั่วโมงการทำงานแบบจัด ให้ได้ใกล้เคียงชั่วโมงสูงสุดที่ทำได้ (12 ชั่วโมง) ดังนั้นข้อดีของการพิจารณาชั่วโมงการทำงานแบบ $8-12$ ชั่วโมงต่อครั้ง คือมี ความยืดหยุ่นด้านเวลาในการทำงานของพนักงานขับรถและสามารถช่วยลดเวลาในการเดินทางของพนักงานขับได้ดีกว่า

2. จุดเปลี่ยนพนักงานขับรถ หมายถึงจุดที่มีคุณสมบัติสำหรับการพิจารณาให้มีการพักหรือเปลี่ยนการทำงานของ พนักงานขับรถได้ พิจารณาลักษณะการทำงาน 2 แบบต่อไปนี้

(1) จุดเปลี่ยนพนักงานขับรถแบบมีจุดเปลี่ยนคนสำรอง

(2) จุดเปลี่ยนพนักงานขับรถแบบไม่มีจุดเปลี่ยนคนสำรอง

การทดสอบจะนำค่าใช้จ่ายในการเดินทางที่เกิดขึ้นจากแต่ละแบบมาเปรียบเทียบกัน โดยอาศัยโจทย์ปัญหาที่มีชุด ข้อมูล 2 ชุด แต่ละชุดประกอบด้วยข้อมูล 60 ตัวอย่าง ซึ่งชุดข้อมูลจะแบ่งตามการพิจารณาจุดเปลี่ยนพนักงานขับรถ และ คำถามในการทดสอบนี้คือ ลักษณะการทำงานที่แตกต่างกันมีผลต่อจำนวนชั่วโมงการเดินทางหรือไม่อย่างไร ภายใต้โจทย์ ปัญหาที่มีข้อมูลชุดเดียวกัน โดยผลการทดสอบแสดงดังรูปที่ 4 (ข้อมูลเส้น $B$ และ $D$ ) พบว่าการพิจารณาจุดเปลี่ยนพนักงาน ขับรถแบบมีจุดเปลี่ยนคนสำรองให้ผลจำนวนชั่วโมงในการเดินทางน้อยกว่าแบบไม่มีจุดเปลี่ยนคนสำรอง โดยเปอร์เซ็นต์ ความแตกต่างอิิบายได้ดังสมการ (4)

$\%$ ความแตกต่างจุดเปลี่ยนคนสำรอง $=$

ชั่วโมงการเดินทางแบบไม่มีจุดเปลี่ยนคนสำรอง - ชั่วโมงการเดินทางแบบไม่มีจุดเปลี่ยนคนสำรอง ชั่วโมงการเดินทางแบบไม่มีจุดเปลี่ยนคนสำวอง

จากการทดสอบโจทย์ปัญหาทั้ง 60 ตัวอย่างพบว่า ค่าเฉลี่ยของเปอร์เซ็นต์ความแตกต่างเท่ากับ $28 \%$ และจากกราฟรูป ที่ 4 จะเห็นได้ว่า ระยะเวลาโดยเฉลี่ยของการเดินทางภายในกลุ่มเพิ่มขึ้นจะได้ค่าความแตกต่างของจำนวนชั่วโมงการ 
เดินทางทั้ง 2 แบบเพิ่มขึ้น เหตุผลหนึ่งเนื่องจาก เมื่อมีการพิจารณาจุดเปลี่ยนคนสำรองในระบบ จะทำให้มีจำนวนจุดเปลี่ยน พนักงานขับรถเพิ่มขึ้น ซึ่งการพิจารณาเปรียบเทียบหาจุดที่เหมาะสมจะมีได้หลายจุดมากกว่า และทำให้มีโอกาส เปรียบเทียบเลือกจุดที่ดีที่สุด ซึ่งส่งผล ให้จำนวนชั่วโมงการเดินทางมีค่าน้อยกว่าด้วยเช่นกัน ดังนั้นสรุปได้ว่า ลักษณะการ ทำงานที่แตกต่างกันมีผลต่อจำนวนชั่วโมงการเดินทาง ซึ่งลักษณะการทำงานแบบมีจุดเปลี่ยนคนสำรองให้ค่าใช้จ่ายในการ เดินทางซึ่งแปรผันตามจำนวนชั่วโมงการเดินทางน้อยกว่าแบบไม่มีจุดเปลี่ยนคนสำรอง

3. ระยะเวลาโดยเฉลี่ยของการเดินทางภายในกลุ่ม หมายถึงค่าเฉลี่ยของระยะเวลาการเดินทางทุกสถานที่ทั้งหมดใน ระบบมีหน่วยเป็นชั่วโมง สาเหตุที่นำปัจจัยนี้มาทดสอบเนื่องจากในงานวิจัยนี้ได้นำเสนอวิธีฮิวริสติกโดยกำหนดให้รูปแบบ ของสถานที่ในระบบมีความหลากหลายทั้งแบบรวมกลุ่มและมีการกระจาย

การทดสอบจะนำค่าใช้จ่ายในการเดินทางที่เกิดขึ้นจากแต่ละแบบมาเปรียบเทียบกัน โดยอาศัยโจทย์ปัญหาที่มีชุด ข้อมูล 4 ชุด แต่ละชุดประกอบด้วยข้อมูล 60 ตัวอย่าง ซึ่งชุดข้อมูลจะแบ่งตามชั่วโมงการทำงานต่อครั้งและการพิจารณาจุด เปลี่ยนพนักงานขับรถ ซึ่งคำถามในการทดสอบนี้คือ ระยะเวลาโดยเฉลี่ยของการเดินทางภายในกลุ่มที่แตกต่างกันออกไปจะ ส่งผลต่อจำนวนชั่วโมงในการเดินทางหรือไม่อย่างไร ภายใต้โจทย์ปัญหาที่มีข้อมูลชุดเดียวกัน ซึ่งพิจารณาคำตอบของชั่วโมง การทำงานต่อครั้งและจุดเปลี่ยนพนักงานขับรถที่ค่าต่าง ๆ กล่าวคือพิจารณาระยะเวลาเดินทางทั้งหมดโดยเฉลี่ยเท่ากับ 3 , $5,6,9,11$ และ 14 ชั่วโมงตามลำดับ โดยผลการทดสอบแสดงดังรูปที่ 4

จากผลการทดสอบโจทย์ปัญหาทั้ง 240 ตัวอย่างพบว่า เมื่อระยะเวลาโดยเฉลี่ยของการเดินทางภายในกลุ่มเพิ่มขึ้น โดย ชั่วโมงการทำงานต่อครั้งและจุดเปลี่ยนพนักงานขับรถยังคงเป็นรูปแบบเดิม จะให้ค่าความแตกต่างของจำนวนชั่วโมงการ เดินทางสูงขึ้นตามลำดับ และเมื่อพิจารณาชั่วโมงการทำงานต่อครั้งพบว่า ชั่วโมงการทำงานแบบเท่ากับ $8-12$ ชั่วโมงต่อครั้ง มีจำนวนชั่วโมงการเดินทางน้อยกว่าจัดให้ได้ใกล้เคียงชั่วโมงสูงสุดที่ทำได้ (12 ชั่วโมง) นอกจากนั้นยังพบว่าจุดเปลี่ยน พนักงานขับรถแบบมีจุดเปลี่ยนคนสำรองให้จำนวนชั่วโมงการเดินทางน้อยกว่าแบบไม่มีจุดเปลี่ยนคนสำรองด้วย จากกราฟ รูปที่ 4 จะเห็นได้ว่า ระยะเวลาโดยเฉลี่ยของการเดินทางภายในกลุ่มเพิ่มขึ้น ความแตกต่างของจำนวนชั่วโมงการเดินทางจะ เพิ่มขึ้นตามไปด้วย เนื่องจาก

- เมื่อระยะเวลาโดยเฉลี่ยของการเดินทางภายในกลุ่มเพิ่มขึ้น นั่นคือการเดินทางระหว่างสถานที่มีระยะเวลานานขึ้น ส่งผลให้มีจำนวนจุดเปลี่ยนคนสำรองมากตามไปด้วย ทำให้การพิจารณาหาจุดเปลี่ยนพนักงานขับรถมีความ เป็นไปได้หลายจุดเพิ่มขึ้น จึงเพิ่มโอกาสเปรียบเทียบเลือกหาจุดที่เหมาะสม และการทดสอบถ้ามีการพิจารณา ชั่วโมงการทำงานแบบ $8-12$ ชั่วโมงต่อครั้งจะทำให้ได้คำตอบที่ดีขึ้นเมื่อเปรียบเทียบกับชั่วโมงการทำงานแบบจัด ให้ได้ใกล้เคียงชั่วโมงสูงสุดที่ทำได้ (12 ชั่วโมง)

- เมื่อระยะเวลาโดยเฉลี่ยของการเดินทางภายในกลุ่มมีค่าน้อยส่งผลให้เกิดจำนวนจุดเปลี่ยนคนสำรองน้อย ดังนั้น การเปรียบเทียบเลือกจุดเปลี่ยนพนักงานขับรถด้วยจำนวนชั่วโมงการเดินทางและจุดเปลี่ยนสำรองแบบใดก็ตาม จะไม่ส่งผลต่อค่าความแตกต่างของจำนวนชั่วโมงการเดินทางเท่าใดนัก

จากผลทดสอบพบว่า ระยะเวลาโดยเฉลี่ยของการเดินทางภายในกลุ่มมีผลต่อค่าใช้จ่ายในการเดินทางที่ แปรผันตาม จำนวนชั่วโมงการเดินทาง 


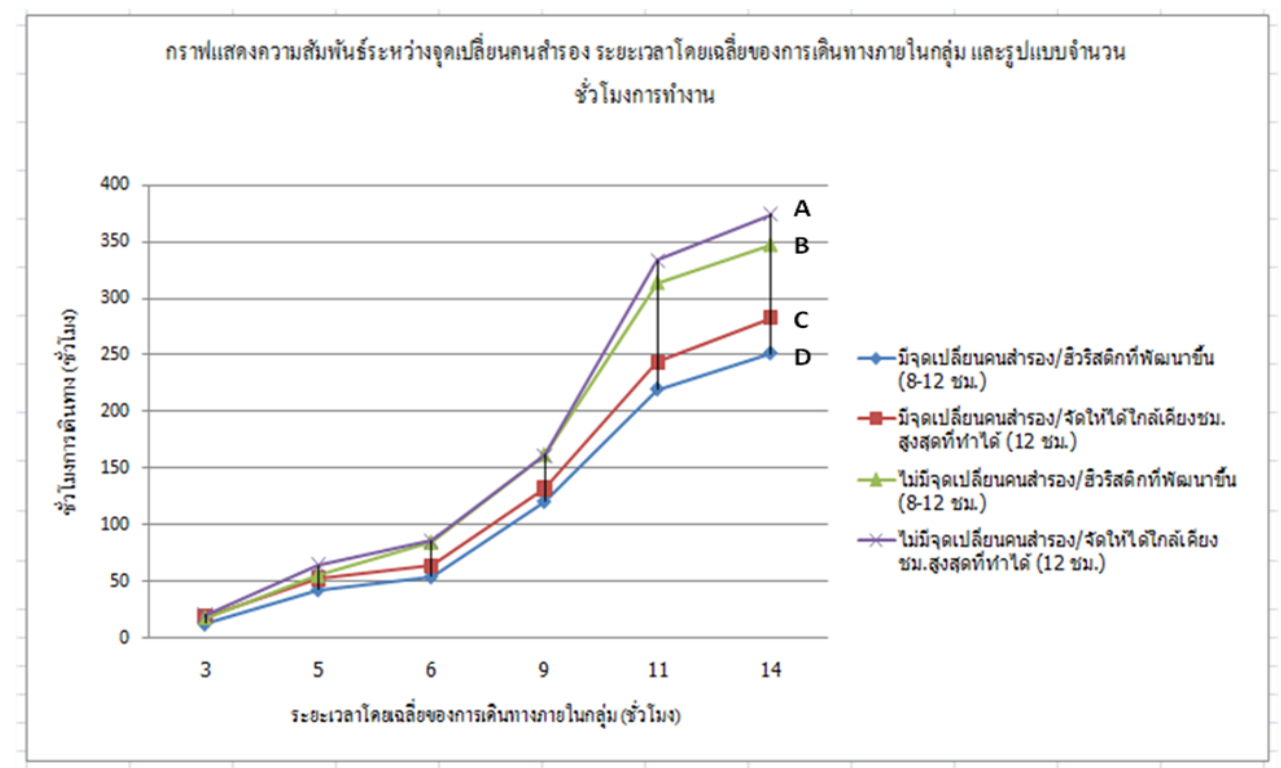

รูปที่ 4 ความสัมพันธ์ระหว่างจุดเปลี่ยนคนสำรอง ระยะเวลาโดยเฉลี่ยของการเดินทางภายในกลุ่มและจำนวนชั่วโมงการ ทำงาน

\section{2. ทดสอบกับวิธีการอื่น}

\section{ขั้นตอนนี้เป็นการเปรียบเทียบฮิวริสติก 2 แบบ คือ}

แบบที่ 1 คือ การคำนวณด้วยวิธี ฮิวริสติกที่ทางผู้วิจัยพัฒนาขึ้น (From this research)

แบบที่ 2 คือ การคำนวณด้วยวิธีฮิวริสติกที่มีลักษณะเป็นการมอบหมายงานให้กับพนักงานขับรถอย่างง่าย (Naive Method) ซึ่งเป็นรูปแบบการทำงานที่มาจากการวางแผนโดยใช้ประสบการณ์ของพนักงานเพียงอย่างเดียว

จากฮิวริสติกทั้ง 2 แบบ พนักงานขับรถสามารถทำงานและมีข้อจำกัดด้านเวลาการทำงานที่เหมือนกันแต่มีความ แตกต่างที่จำนวนชั่วโมงการทำงานต่อครั้งและรูปแบบการพิจารณาวางแผนมอบหมายงาน สามารถสรุปความแตกต่างของ ฮิวริสติกทั้ง 2 แบบได้ดังตารางที่ 1

วัตถุประสงค์ของการทดสอบ คือฮิวริสติกที่พัฒนาขึ้น (From this research) มีความสามารถที่ดีกว่าฮิวริสติกที่มีรูปแบบ การมอบหมายงานให้กับพนักงานขับรถอย่างง่ายที่เกิดจากประสบการณ์ของพนักงานอย่างเดียว (Naive Method) โดยฮิวริ สติกที่พัฒนาขึ้นจะมีประสิทธิภาพดีกว่าอย่างไร ในการทดสอบจะนำค่าใช้จ่ายในการเดินทางที่เกิดขึ้นจากแต่ละแบบมา เปรียบเทียบกันโดยอาศัยโจทย์ปัญหาที่มีชุดข้อมูล 2 ชุด แต่ละชุดประกอบด้วยข้อมูล 60 ตัวอย่าง ซึ่งแต่ละชุดข้อมูลจะแบ่ง ตามวิธีฮิวริสติก และคำถามในการทดสอบนี้คือ ค่าใช้จ่ายในการเดินทางที่ได้จากฮิวริสติกทั้ง 2 แบบมีความแตกต่างกัน หรือไม่อย่างไร ภายใต้โจทย์ปัญหาที่มีข้อมูลชุดเดียวกัน ผลการทดสอบแสดงดังรูปที่ 5 
ตารางที่ 1 ความแตกต่างระหว่างฮิวริสติกที่ทางผู้วิจัยพัฒนาขึ้น (From this research) กับฮิวริสติกที่มีรูปแบบการ มอบหมายงานให้กับพนักงานขับรถอย่างง่าย (Naive Method)

\section{ฮิวริสติกที่ผู้วิจัยพัฒนาขึ้น}

(From this research)

1. คำนึงถึงการวางแผนในรอบก่อนหน้า

2. พิจารณาจัดลำดับรถเพื่อการวางแผน

3. พิจารณาชั่วโมงการทำงานต่อครั้งเท่ากับ $8-12$ ชั่วโมง

4. พิจารณาวางแผนทุกเส้นทางทั้งหมดที่มี (Multi-route)

\section{ฮิวริสติกที่มีรูปแบบการมอบหมายงาน} ให้กับพนักงานขับรถอย่างง่าย (Naive Method)
2. ไม่มีการพิจารณาจัดลำดับรถเพื่อการวางแผน

3. พิจารณาชั่วโมงการทำงานต่อครั้งจัดให้ได้ใกล้เคียง ชั่วโมงสูงสุดที่ทำได้ (12 ชั่วโมง)

4. พิจารณาวางแผนทีละเส้นทาง (Single-route)

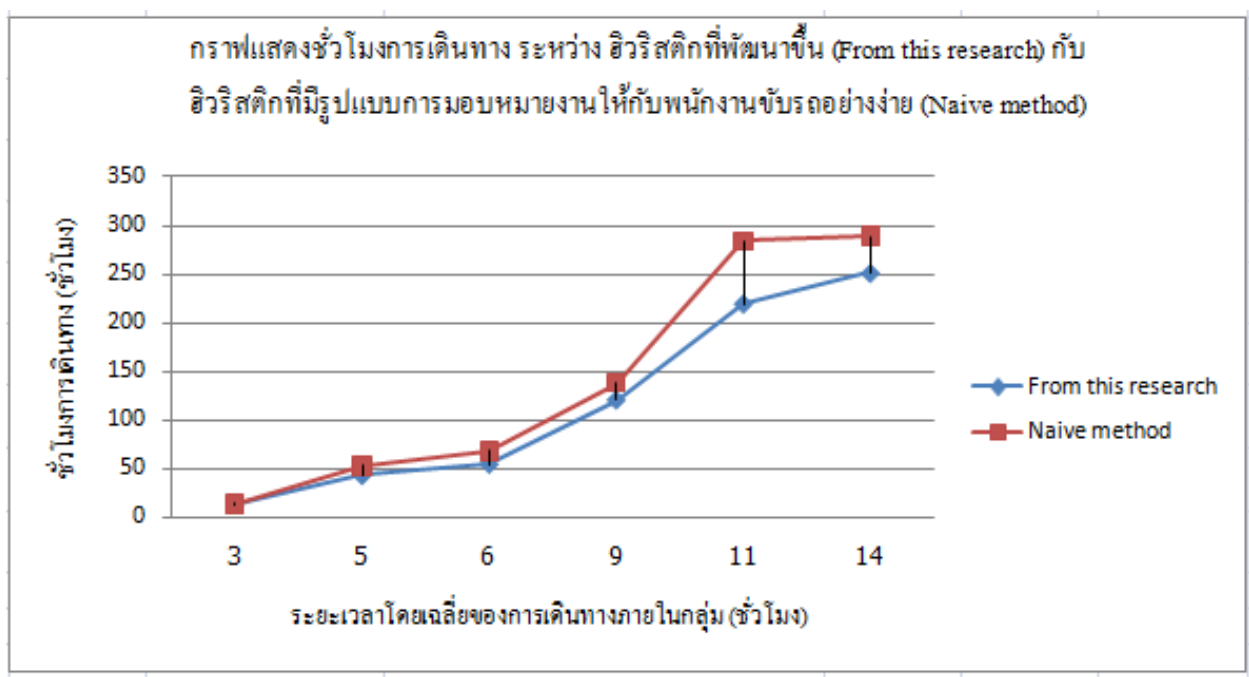

รูปที่ 5 ความสัมพันธ์ระหว่างระยะเวลาโดยเฉลี่ยของการเดินทางภายในกลุ่มกับชั่วโมงการเดินทางด้วยวิธีฮิวริสติกที่ พัฒนาขึ้นเปรียบเทียบกับวิธีการมอบหมายงานแบบง่าย

จากผลการทดสอบโจทย์ปัญหาทั้ง 60 ตัวอย่าง พบว่า วิธีฮิวริสติกที่ทางผู้วิจัยพัฒนาขึ้นให้จำนวนชั่วโมงการเดินทางมี ค่าน้อยกว่าฮิวริสติกที่มีรูปแบบการมอบหมายงานให้กับพนักงานขับรถอย่างง่าย (Naive Method) และสามารถช่วยลด ค่าใช้จ่ายในการเดินทางของพนักงานขับรถลงได้ประมาณ $15.23 \%$ โดยเปอร์เซ็นต์ความแตกต่างอธิบายได้ดังสมการ (5)

$\%$ ความแตกต่างของวิธีการมอบหมายงาน =

$\frac{\text { ชั่วโมงการเดินทางจากวิธีธิวริสติกการมอบหมายงานอย่างง่าย -ชั่วโโมงการเดินทางจากวิธีธิธิวริสติกที่ทางผู้วิจัยพัฒนาขึ้น }}{\text { ชั่วโมงการเดินทางจากวีธิธิวริสติกการมอบหมายงานอย่างง่าย }} \times 100$

ผลการทดสอบเปอร์เซ็นต์ที่ลดลงนี้ได้จากลักษณะของโจทย์ปัญหาตัวอย่าง โดยกราฟรูปที่ 5 จะเห็นได้ว่า เมื่อระยะเวลา โดยเฉลี่ยของการเดินทางภายในกลุ่มเพิ่มขึ้น จะได้ค่าความแตกต่างของทั้ง 2 แบบเพิ่มขึ้นเช่นกัน เนื่องจากการพิจารณา วางแผนจัดเส้นทางครั้งละมากกว่าหนึ่งเส้นทางนั้น จะมีโอกาสเกิดจุดเปลี่ยนพนักงานขับรถที่เหมาะสมมากกว่าและสงผลมี 
โอกาสเกิดค่าใช้จ่ายในการเดินทางที่ต่ำกว่าอีกด้วย สรุปได้ว่าวิธีฮิวริสติกที่ทางผู้วิจัยพัฒนาขึ้นมีรูปแบบของการมอบหมาย งานให้กับพนักงานขับรถที่สามารถช่วยลดค่าใช้จ่ายที่เกิดจากการเดินทางของพนักงานขับรถได้ดีกว่าการคิดวิธีการ มอบหมายงานแบบง่าย และนำมาซึ่งค่าใช้จ่ายในระบบที่ลดลง นอกจากนี้พบว่า คำตอบจากวิธีฮิวริสติกที่ทางผู้วิจัยพัฒนา ขึ้นให้ค่าใช้จ่ายในการเดินทางซึ่งแปรผันตามจำนวนชั่วโมงการเดินทางน้อยกว่าฮิวริสติกที่มีรูปแบบการมอบหมายงานให้กับ พนักงานขับรถอย่างง่ายและสามารถลดค่าใช้จ่ายในการเดินทางได้มากกว่า

\section{6. บทสรุปและข้อเสนอแนะ}

บทความวิจัยนี้เป็นการนำเสนอวิธีฮิวริสติก (Heuristic) สำหรับการมอบหมายงานให้กับพนักงานขับรถ โดยที่มีแผนเส้นทาง ขนส่งแบบต่อเนื่องที่วางแผนไว้แล้ว จากผลการทดสอบจะเห็นได้ว่าฮิวริสติกที่พัฒนาขึ้นสามารถสรุปได้ว่าปัจจัยที่มี ผลกระทบต่อรูปแบบของคำตอบจากการคำนวณด้วยระบบสนับสนุนการมอบหมายงานให้กับพนักงานขับรถที่มีรูปแบบการ เดินรถแบบต่อเนื่องได้แก่ จำนวนชั่วโมงการทำงานต่อครั้ง จุดเปลี่ยนคนสำรอง และระยะเวลาโดยเฉลี่ยของการเดินทาง ภายในกลุ่ม นอกจากนี้ฮิวริสติกที่พัฒนาขึ้นโดยมีการพิจารณาแบบวางแผนทุกเส้นทางทั้งหมดที่มีอยู่ (Multi-route) ให้ ค่าใช้จ่ายในการเดินทางที่น้อยกว่าแบบวางแผนทีละเส้นทาง (Single-route) คิดเป็น $15.23 \%$ ซึ่งฮิวริสติกที่พัฒนาขึ้น สามารถช่วยสามารถลดต้นทุนการเดินทางของพนักงานขับรถ พร้อมตอบสนองต่อความต้องการของแผนเส้นทางขนส่ง สามารถรับและส่งสินค้าได้ตามเวลาที่กำหนด ช่วยให้การตัดสินใจของผู้ใช้งานลดความยุ่งยากซับซ้อนในการทำงาน มี ประสิทธิภาพโดยใช้ทรัพยากรอย่างคุ้มค่า อย่างไรก็ตามสำหรับปัญหาการมอบหมายงานที่ได้ศึกษาในบทความวิจัยนี้ถูก จำกัดด้วยลักษณะเฉพาะบางประการของรูปแบบการทำงานที่ศึกษาเท่านั้น เพื่อให้ตอบสนองต่อรูปแบบการเดินรถ แบบต่อเนื่อง เช่น รถสามารถวิ่งได้ 24 ชั่วโมง ส่งผลให้ไม่สามารถกำหนดรอบเวลาการทำงานของพนักงานขับรถที่แน่นอนได้ เป็นต้น ในการนำฮิวริสติกในงานวิจัยนี้ไปประยุกต์ใช้จะต้องคำนึงถึงการปรับข้อจำกัดต่าง ๆ เช่น ข้อกำหนดด้านเวลาการ ทำงาน ข้อจำกัดการขับรถหลากหลายประเภท ให้ตรงกับลักษณะการทำงานรูปแบบนั้น ๆ ด้วย 


\section{บรรณานุกรม}

[1] “ตัวชี้วัดประสิทธิภาพด้านโลจิสติกส์: LPI ตามโครงการศูนย์บริการข้อมูลโลจิสติกส์ (Logistics Service Information Center: LSIC)," สำนักโลจิสติกส์ กรมอุตสาหกรรมพื้นฐานและการเหมืองแร่ กระทรวงอุตสาหกรรม, 2553.

[2] สุภีจรรย์ หุ่นธานี, "การออกแบบระบบสนับสนุนการตัดสินใจเพื่อการจ่ายงานให้พนักงานในงานเย็บผ้า," วิทยานิพนธ์ ปริญญามหาบัณฑิต, ภาควิชาวิศวกรรมอุตสาหการ คณะวิศวกรรมศาสตร์ บัณฑิตวิทยาลัย จุฬาลงกรณ์ มหาวิทยาลัย, 2551.

[3] จุฑามาศ เทวินบุรานุวงศ์, "การประยุกต์เจนเนติกอัลกอริทึมสำหรับการจัดตารางเวรของพยาบาลประจำการ," วิทยานิพนธ์ปริญญามหาบัณฑิต, ภาควิชาวิศวกรรมอุตสาหการ คณะวิศวกรรมศาสตร์ บัณฑิตวิทยาลัย จุฬาลงกรณ์ มหาวิทยาลัย, 2543.

[4] I. Blochliger, "Modeling staff scheduling problem. A tutorial," European Journal of Operational Research, vol. 158, no. 3, p. 533-542, 2004.

[5] A. Goel, C. Archetti, and M. Savelsbergh, "Truck driver scheduling in Australia," Computers \& Operations Research, vol. 39, no. 5, pp. 1122-1132, 2012.

[6] R. Anbil, J. J. Forrest and W. R. Pulleyblank, "Column generation and the airline crew pairing problem," Mathematics Subject Classification 90B35 90C09 90C10, p. 677, 1991.

[7] R. Anbil, R. Tanga and E. L. Johnson, "A global approach to crew-pairing optimization," IBM Systems Journal, vol. 31, no. 1, 1992.

[8] S. Yan and J. C. Chang, "Airline cockpit crew scheduling," European Journal of Operational Research, vol. 136, no. 3, pp. 501-511, 2001.

[9] A. Goel and L. Kok, "Truck driver scheduling in the United States," Transportation Science, vol. 46, no. 3, pp. 317-326, 2010.

[10] ณกร อินทร์พยุง. การแก้ปัญหาการตัดสินใจในอุตสาหกรรมขนส่งและลอจิสติกส์. กรุงเทพมหานคร: ซีเอ็ดยูเคชั่น, 2548 . 
